\title{
THE RAM GIRGLE AS A PROGENY TESTING METHOD
}

\author{
Jouko SyväJärvi \& Mikko Varo \\ Department of Animal Breeding, University of Helsinki, Finland
}

Received January 20, 1972

\begin{abstract}
Ram circles are used to obtain progeny from sire rams on a number of different farms in order that the effect of farm on progeny may be equalized and, concurrently, the selection of mate be a random one. The objective is the achievement of reliable progeny evaluations of the rams as a result of cooperation between farms. The Finnish experiment covered four farms, and four rams were used to service the four flocks containing a total of 66 ewes. In the spring, 163 lambs were born. In the autumn 40 male lambs were selected from this number at random and were slaughtered, dissected and evaluated. The results were analysed by covariance analysis, and the effects of the dam, the litter and the age of animal were eqalized. The effect of the farm on the early growth and the liveweight of the lambs was considerable, but it decreased with the ageing of the lambs. The effect of farm on the characteristics of the carcass was without significance. The variation between sires was greater than the variation due to error concerning almost all the characteristics, and in four cases the differences were significant at a probability level of 95 per cent. The differences will probably emerge more clearly if the number of farms and the number of rams in the circle are increased. In the experiment this time the number of progeny on the various farms was far from even. On the basis of slaughter results, however, estimates could be produced of the order of superiority of the sires.
\end{abstract}

Finnish statistics for 1968 show that there were only 12.7 ewes per farm on an average. The progeny group that is necessary for progeny testing can consequently hardly be obtained for the average Finnish flock for more than one ram, and thus no selection can be made. Conversely, no comparisons can be made directly between the rams on the various farms which have produced progeny, for the effect of the flock cannot be distinguished from the effect of the sire.

To make field evaluations possible in the conditions outlined above, a system of ram circle has been in use in Norway since 1956. GJEDREM (1969) states that the method is employed to ensure that each of the rams will have progeny on the various farms, in order that the effects of the flocks on the progeny groups might be distributed as evenly as possible. Random selection of mate is attempted. In practice the sheep breeders within a specified area use the same rams for servicing. The servicing is started simultaneously on the farms, and the rams are circulated daily during the breeding season from farm to farm. Thus in every flock the rams will service those ewes that come into heat on the day concerned and the lambs will be born close to one another in time.

The Sheep Breeding Society began to study the possibilities of applying the ram 
circle system in Finland by setting up a ram circle in 1968 - 1969. Analyses were concurrently made of the variation and hereditability of meat production features of sheep.

This experiment was set up on four farms in the vicinity of Pieksämäki. The experiment included four rams which were circulated from one farm to another at intervals of five days. On three of the farms the servicing began on October 18th 1968. On one of these one of the rams had already been in the flock for a few days. The rams were transferred three times, and after the third transfer they remained with the same flock to the end of the breeding season.

The lambs born were weighed not only at the ordinary testing but also at the age of c. 120 days. Likewise, 40 lambs were selected at random among the male lambs and were slaughtered at the slaughterhouse of Osuusteurastamo Karjaportti at Mikkeli. The liveweight of the selected lambs was also taken about one week before slaughter. The carcasses were cut up acording to commercial practice. The left side of the carcass was dissected in order to establish the proportions of meat and bone. Table 1 shows the means and standard deviations of the characteristics.

Table 1. Means, standard deviations, variation percentages and heritabilities of characteristics.

\begin{tabular}{|c|c|c|c|c|c|}
\hline Characteristic & & Mean & $\begin{array}{c}\text { Stand. } \\
\text { dev. }\end{array}$ & $\begin{array}{l}\text { Varia- } \\
\text { tion } \%\end{array}$ & $\mathrm{~h}^{2}$ \\
\hline \multicolumn{6}{|l|}{ Living 1 a mbs } \\
\hline Weight at age of 120 days & $\mathrm{g}$ & 27076 & 3410 & 12.59 & 0.06 \\
\hline Weight at age of 150 days & $\mathrm{g}$ & 32016 & 3538 & 11.05 & 0.27 \\
\hline \multicolumn{6}{|l|}{ Carcasses } \\
\hline Left half of carcass & g & 6488 & 1164 & 17.94 & 0.40 \\
\hline Breast part & g & 2758 & 489 & 17.73 & 0.53 \\
\hline Back part & g & 626 & 158 & 25.23 & 0.49 \\
\hline Loin part & g & 983 & 216 & 22.06 & 0.18 \\
\hline Leg part & $\mathrm{g}$ & 2119 & 342 & 16.13 & 0.25 \\
\hline Shoulder & $\mathrm{g}$ & 1277 & 214 & 16.73 & 0.64 \\
\hline Meat, total & g & 2910 & 526 & 18.08 & 0.41 \\
\hline Fillet & g & 304 & 79 & 25.96 & 0.00 \\
\hline Meat of leg & g & 1597 & 282 & 17.67 & 0.29 \\
\hline Meat of shoulder & g & 1009 & 184 & 18.26 & 0.72 \\
\hline Bones of leg & g & 521 & 65 & 12.42 & 0.13 \\
\hline Bones of shoulder & g & 268 & 35 & 13.16 & 0.44 \\
\hline Total meat, $\%$ of carcass & & 44.89 & 1.80 & 4.10 & 0.00 \\
\hline Fillet, $\%$ of saddle and leg & & 19.10 & 4.21 & 22.07 & 0.00 \\
\hline Percentage of meat in leg & & 75.08 & 1.88 & 2.50 & 0.47 \\
\hline Percentage of meat in shoulder & & 78.72 & 1.69 & 2.15 & 0.97 \\
\hline Slaughter percentage & & 37.92 & 2.76 & 7.27 & 0.00 \\
\hline Leg, \% of carcass weight & & 32.81 & 1.48 & 4.50 & 0.10 \\
\hline Slaughter points & & 13.98 & 1.52 & 10.89 & 0.64 \\
\hline Fullnes of meat in carcass, points & & 8.98 & 1.31 & 14.63 & 0.69 \\
\hline
\end{tabular}

N.B. All slaughter characteristics measured from left half of carcass. 
Table 2. Numbers of ewes and the size of the progeny groups of rams and ewes per farm and in total.

\begin{tabular}{ccccrrrrr}
\hline Farm & Lambs/ & Ewes/ & \multicolumn{5}{c}{ Ram } & \\
\cline { 5 - 7 } No. & ewe & farm & & I & II & III & IV & Total \\
\hline 1 & 2.6 & 21 & 5 & 32 & 2 & 10 & 54 \\
2 & 2.5 & 13 & 0 & 25 & 7 & 0 & 32 \\
3 & 2.2 & 13 & 5 & 4 & 0 & 19 & 28 \\
4 & 2.6 & 19 & 0 & 2 & 37 & 10 & 49 \\
\hline \multirow{2}{*}{ Tot. } & 2.5 & 66 & 10 & 68 & 46 & 39 & 163 \\
\hline
\end{tabular}

Table 2 shows the size of the flocks on the various participating farms and the frequency distributions of lambs born. It appears that the rams produced progeny on the farms somewhat unevenly, for only one of them had progeny on every farm. This factor makes it difficult to interpret the results and may have made it impossible reliably to separate the variation between rams from that existing between flocks.

The results were analysed at the National Computer Centre by means of a covariance analysis programme prepared for Elliot 503 and based on the method of least squares presented by HARveY (1960).

In order to ascertain the significance of factors affecting the weights taken at various ages and the respective growth rate, use was made of the model

$$
y_{i j k 1}=\alpha+g_{i}+s_{i j}+a_{k}+b A_{i j k 1}+d_{i j k 1}+f_{i j k 1}+h_{i j k 1}+e_{i j k 1}
$$

where $y_{i j k 1}=$ the estimate of the respective characteristic of the lamb born on the $i^{\text {th }}$ farm as progeny of the $\mathrm{j}^{\text {th }}$ ram of $\mathrm{k}^{\text {th }}$ sex,

$\alpha=$ the theoretical mean of the population, assuming that the observations are distributed evenly on the various levels of the classes, and that

$\mathrm{A}_{\mathrm{ijk1}}=\mathrm{B}_{\mathrm{ijk} 1}=\mathrm{C}_{\mathrm{ijk1}}=\mathrm{D}_{\mathrm{ijk1}}=0$,

$\mathrm{g}_{\mathrm{i}}=$ effect of $\mathrm{i}^{\text {th }}$ farm,

$s_{i j}=$ effect of $j^{\text {th }}$ sire with in $i^{\text {th }}$ farm,

$a_{k}=$ effect of $k^{\text {th }}$ sex,

$A_{i j k 1}=$ age of dam,

$B_{i j k 1}=$ weight of dam,

$\mathrm{C}_{\mathrm{ijk1}}=$ number of lambs in litter,

$\mathrm{D}_{\mathrm{ijk} \mathbf{k}}=$ time of lambing,

$\mathrm{b}, \mathrm{d}, \mathrm{f}, \mathrm{h}=$ partial regressions of the $\mathrm{y}_{\mathrm{ijkl}}$ on the equivalent regression variables,

$\mathrm{e}_{\mathrm{ijk} \mathbf{1}}=$ random error, distribution of which is assumed to be normal.

\section{Variation in growth characteristics}

In order to ascertain the effect of the dam, the dam's age and weight as regression variables were included in all analyses. It was found that initially the progeny of the older ewes grew faster than did the progeny of the younger ewes, but that later they grew more slowly. A similar result has been arrived at among others by Hazel and TerriL 
Table 3. Results of covariance analysis of daily growths.

\begin{tabular}{|c|c|c|c|c|}
\hline \multirow{2}{*}{ Source of variation } & \multirow{2}{*}{ DF } & \multicolumn{3}{|c|}{ Mean squares } \\
\hline & & $0-120$ days & $0-150$ days & $120-150$ days \\
\hline Regr. of dam's age & 1 & $368.10770^{*}$ & 1097.0519 & 6630.1564 \\
\hline Regr. of dam's weight & 1 & 2735.1942 & 1828.8057 & 2099.2741 \\
\hline Regr. of type of rearing & 1 & $21080.059 * * *$ & $12849.062^{* * *}$ & 2278.9065 \\
\hline Regr. of lambing time & 1 & 613.89243 & 10.124490 & 1376.0178 \\
\hline Sex & 1 & $18744.062 * * *$ & $20270.364 * * *$ & $23092.723 * *$ \\
\hline Farm & 3 & $6781.7620 * * *$ & $6437.8230 * * *$ & 5213.0760 \\
\hline Sires within farms & 8 & 1007.6814 & 1084.8680 & 3394.6806 \\
\hline Error & 98 & 802.36049 & 579.65641 & 2393.7148 \\
\hline Total & 114 & & & \\
\hline
\end{tabular}

(1945). According to them, the high initial growth rate in the progeny of older ewes is due to the fact that the milk production capacity of ewes is at its maximum at the age of $5-6$ years. The weight of the dam had no significant effect on the growth of the progeny. This is evident from Table 3.

Table 3 also shows that the effect of the type of rearing on the growth of the progeny is very significant. The effect, however, did weaken in the same manner as did that of the age of the dam. According to Rendel (1954) the rapid initial growth of lambs born in small litters is due to the fact that at this stage they get more milk than do lambs born in large litters. Later, when they all begin to eat fodder, the differences disappear and the lambs of large litters tend to catch up in weight. Table 3 also shows that the regression between the type of rearing and the growth during the period from 120-150 days was no longer significant.

Nor does the time of lambing seem to have any effect on the growth rate. In contrast, the differences between sexes were clear during all the periods of growth. The farm of birth likewise had a definite effect on the growth of the young lambs, but no longer on the growth occurring during days 120-150. It seems that if the rams are evaluated on the basis of living progeny, the effects of at least the type of rearing and the sex of the lamb and, among younger lambs, of the dam's age, must be equalized before progeny testing. Account should then also be taken of the effect of the farm of birth.

\section{Factors affecting variation in slaughter characteristics}

When the factors affecting the variation in the carcass characteristics of 40 slaughtered male lambs were analysed in accordance with the above model, it was found that the variation between farms in the various characteristics was generally smaller than the variation in error. Also the variation between sires within farms was greater than was the variation between farms. Consequently, a final model explaining the slaughter characteristics was drawn up without separation of the component of variation between farms. The effect of sex, of course, was not separated, as the slaughtered lambs were all males.

The effect of the characteristics selected as regression variables was not significant, 
with the exeption of the time of birth. This connection too must be regarded as being chiefly due to the age, as all the male lambs were slaughtered on the same day, and the time of birth was expressed by the number of days from the turn of the year to the date of birth. Calculating in accordance with the model, the weight of the half-carcass of a lamb that was one day older would be $45 \mathrm{~g}$ greater if other regression variables are assumed to remain unchanged.

Between sires the differences were significant in four characterisrics only when a total of 20 characteristics were examined, but is should be noted that only 4 sires were evaluated.

Table 4 shows that the parameters for the various characteristics calculated for the sires regulary vary in a single direction from the theoretical mean of the respective characteristic. At a cautious estimate, the progeny of the III sire seem to be the poorest and those of sire II the next poorest, although the differences were generally not statistically significant.

Table 4. Estimates of the least-squares constants for the sires from the most important characteristics of the carcass; and the significance of differences. The observations were made on the left half of the carcass.

\begin{tabular}{|c|c|c|c|c|c|c|}
\hline \multirow[t]{2}{*}{ Characteristic } & & \multicolumn{4}{|c|}{ Sire } & \multirow{2}{*}{$\begin{array}{l}\text { Signi- } \\
\text { ficance }\end{array}$} \\
\hline & & I & II & III & IV & \\
\hline Half carcass & g & 304 & -153 & -656 & 506 & \\
\hline Breast part & g & 203 & -37 & -334 & 168 & \\
\hline Back part & g & -15 & -14 & -76 & 106 & \\
\hline Loin part & g & 14 & -10 & -98 & 94 & \\
\hline Leg part & g & 129 & -63 & -173 & 108 & \\
\hline Shoulder & g & 104 & -15 & -158 & 70 & \\
\hline Meat, total & g & 183 & -52 & -320 & 189 & \\
\hline Meat of leg & g & 87 & -45 & -147 & 105 & \\
\hline Meat of shoulder & g & 82 & -8 & -143 & 69 & * \\
\hline Meat, total of carcass & $\%$ & .66 & .13 & -.37 & -.42 & \\
\hline Meat of leg/carcass & $\%$ & -.23 & .01 & -.97 & 1.19 & \\
\hline Meat of shoulder/carcass & $\%$ & .22 & .21 & -1.46 & 1.03 & $*$ \\
\hline Fullness of meat, points & & -.14 & -.27 & -.63 & 1.04 & $*$ \\
\hline
\end{tabular}

\section{Estimates of heritabilities}

The heritabilities of liveweights and growths were calculated from paternal half-sibs by means of covariance analysis, from values corrected in accordance with the above model. The results are shown in Table 1. GJEDREM (1967) has estimated the heritability of weaning weight in a Norwegian lamb material to be 0.26 , VARo (1968) has calculated the heritability of liveweight as being 0.37, and Majula (1967) gives the heritability of weaning weight as 0.25 . All these correspond closely with the heritability of the weight corrected to the age of 150 days here estimated.

The heritabilities of slaughter characteristics were likewise calculated on the basis of half-sibs correlation. It should be noted that the share of variance between sires in this case was not calculated between farms, because the variation between farms was smaller than the variation due to error. 
It can be seen from Table 1 that the heritability had highly differing values depending on the characteristic concerned.

The estimates of the heritability of the half carcass at 0.40 and that of the total weight of meat at 0.41 is probably of greater interest. BotкIN et al. (1969) calculated the respective values is English races to be 0.33 and 0.39, and VARo (1968) calculated those in a Finnish material to be 0.37 and 0.34 . Thus, at a certain age the weight of the carcass and the meat are at least as clearly heritable as is the growth tendency in general. As the weighing of the carcass and the assessment of the fullness cannot be accurately performed before the slaughterhouse is reached, at least a number of the progeny produced in the ram circle have to be slaughtered in order to make the evaluation certain.

\section{Discussion}

One of the purposes of a ram circle is to have the progeny of different rams distributed into circumstances in order to equalize the effect of the environment, i.e. chiefly the effect of the rearing farm. As was shown in Table 2, however, this was not completely successful on this occasion. One reason may be that on one of the farms the ram had been with the flock before October 18th, the date on which the experiment was initiated. And the success of the method seems to require simultaneous commencement of servicing on all the farms in the circle. Also, the rams should be circulated more frequently than at intervals of five days, for almost all the ewes may come on heat in a small flock within a period of that length.

The variation between farms proved to be significant for growths and liveweights other than those occuring during the age of 120-150 days. The reason for the difference may lie in differences in feeding, or in an uneven distribution of the progeny groups of the sires by farms, because variation was also found between the sires. In any event, it is necessary to attempt to implement the ram circle fully on every farm, so that the effect of farm on progeny group will be levelled out.

The effect of farm of birth on the characteristics of the lambs decreased with increasing age. There was no very clear connection between the carcass characteristics and the investigated environmental factors. In view of progeny evaluation the most important factor requiring any correction may be the age of the animal, for its effect was sinificant on the weight of the meat of the leg, the weight of the loin and the percentage of meat on the leg when the relationship was measured by means of partial regression. Yet 40 slaughtered male lambs must be regarded as being far too small a sample for the evaluation of all factors that require correction.

In the analysis of slaughter results it was found that the variation between farms was generally smaller than the variation due to error. This suggests that the breeding value of the slaughter characteristics of sires can be evaluated by means of a ram circle directly within the circle without the necessity of giving any attention to the effect of the farms.

Differences between sires were generally not significant where growth characteristics were concerned, but became increasily evident with the increasing age of the lambs and concurrent decrease in the variation between farms. Differences between sires in slaughter characteristics at a $5 \%$ risk were significant in four of the characteristics investigated. 


\title{
REFERENCES
}

Botkin, M. P., Field, R. A., Riley, M. L., Nolan, J. C. \& Roehrkasse, Jr \& G. P. 1969. Heritability of carcass traits in lambs. J. Anim. Sci. 29: 251-255.

GJEDrem, T. 1967. Phenotypic and genetic parameters for weight of lambs at five ages. Acta Agr. Scand. 17: $199-216$.

GJedrem, T. 1969. Some attempts to increase the efficiency of sheep selection. Acta Agr. Scand. 19: $166-126$.

HARVeY, W. R. 1960. Least-squares analysis of data with unequal subclass numbers. ARS $20-8$. Agric. Res. Service, U.S. Dep. of Agric. 157 p.

Hazel, L. N. \& Terril, C. E. 1945. Effect of some environmental factors on weanling traits of range Rambouillet lambs. J. Anim. Sci. 4: 331-341.

Majjalı, K. 1967. Lampaan taloudellisten ominaisuuksien periytymisasteet. Maatal. tutk.kesk. tietokortti 7El.

RENDEL, J. 1954. De viktigaste produktionsegenskaperna hos får-variation och nedärvning. Kungl. Lantbruksakad. tidskr. 93, 4: 283-319.

VAro, M. 1968. Lampaiden kasvatuskokeiden tuloksia. Ann. agric. Fenn. 7: 33-45.

\section{SELOSTUS}

\section{PÄSSIRENGAS JÄLKEISARVOSTELUMENETELMÄNÄ}

\author{
Jouko Syväjärvi ja Mikкo Varo \\ Helsingin yliopiston kotieläinten jalostustieteen laitos
}

Pässirenkaan avulla pyritään saamaan isäpässeille talojen vaikutuksen tasoittamiseksi jälkeläisiä useilla eri tiloilla ja samalla parittelukumppanin valinta sattumanvaraiseksi. Tavoitteena on tilojen yhteistyönä saada pässeille luotettavat jälkeläisarvostelut. Suomalaisessa kokeilussa oli mukana neljä tilaa, joiden katraissa käytetyt neljä pässiä astuivat yhteensä 66 uuhta. Keväällä syntyi 163 karitsaa, joista syksyllä 40 sattumanvaraisesti valittua pässikaritsaa teurastettiin, paloiteltiin sekä arvosteltiin.

Tulokset analysoitiin kovarianssianalyysillä, jolloin emän iän ja painon, pahnueen koon ja eläimen iän vaikutus tasoitettiin.

Talojen vaikutus karitsojen varhaiskasvuun ja elopainoon oli voimakas, mutta heikkeni karitsojen vanhetessa. Ruhon ominaisuuksiin oli tilan vaikutus merkityksetön.

Miltei kaikissa ominaisuuksissa oli isienvälinen muuntelu laajempaa kuin virhemuuntelu ja neljässä erot olivat $95 \%$ :n todennäköisyydellä merkitseviä. Lisäämällä renkaan tilojen ja pässien lukumäärää erot tulevat luultavasti selvemmin esille.

Tämänkertaisessa kokeessa ei onnistuttu saamaan jälkeläisiä likimainkaan tasaisesti eri taloihin. Teurastuloksiin perustuen voitiin kuitenkin esittää arvioita isäpässien paremmuusjärjestyksestä. 